\title{
STRATEGI MENINGKATKAN PEMASARAN UNGGAS KAMI MELALUI DESAIN PACKAGING DAN PELATIHAN PENYUSUNAN LAPORAN KEUANGAN BERBASIS EMKM
}

\author{
Fitri Lestari \\ fitri.lestari@ekuitas.ac.id \\ Tri Widiastuty \\ tridesty@yahoo.com \\ Ade Imam Muslim \\ imemmuslim81@gmail.com
}

SEKOLAH TINGGI ILMU EKONOMI EKUITAS

\begin{abstract}
ABSTRAK
Masalah utama yang dialami oleh UNGGAS KAMI adalah mesin penetas telur baru memiliki satu dengan kapasitas 1000 telur, semakin banyak mesin penetas telur maka semakin banyak produksi telur untuk menghasilkan DOD. Setiap mesin penetas harus ada thermostat, thermometer dan hygrometer. Sehingga apabila mesin penetas bertambah, maka thermostat, thermometer dan hygrometer pun harus ada. Inipun berpengaruh pada suplai listrik atau genset, karena mesin penetas telur menggunakan listrik selama proses penetasan 28 hari sehingga untuk mengantisipasi ketika suplai listrik dari PLN padam tanpa pemberitahuan terlebih dahulu, dapat menggunakan genset. Kapasitas genset yang dimiliki 2 kva, oleh karena itu apabila mesin penetas bertambah kapasitas genset juga bertambah. Selain itu, perputaran uang untuk modal megalami kendala dikarenakan banyaknya piutang yang tidak tercatat. Terkait belum memahami penyusunan laporan keuangan. Saat ini mitra belum menyusun laporan keuangannya dan belum paham dalam menghitung modal, biaya produksi, piutang dan laba kotor. Dari segi pemasaran, mitra akan ditawarkan packaging telur asin supaya memiliki daya jual lebih dan tidak hanya DOD yang dipasarkan melalui internet tetapi telur asin juga dapat dipasarkan melalui media promosi yang efektif. Pembenahan pemasaran dengan pemasangan plang nama. Saat ini mitra tidak memiliki identitas atau plang nama di lokasi pemasaran.
\end{abstract}

Kata kunci: Laporan Keuangan EMKM, Packaging

\section{PENDAHULUAN}

Usaha UNGGAS KAMI berdiri pada tahun 2011 yang berlokasi di Kabupaten Garut tepatnya di kecamatan Kadungora. Berawal dari melihat peluang pasar bebek yang menjanjikan serta hobi menyukai hewan unggas. Selain itu, nutrisi (kalori, lemak, kolesterol, protein, mineral dan vitamin) yang ada pada daging bebek lebih banyak dibandingkan dengan ayam. Banyak masyarakat yang lebih menyukai daging bebek dibandingkan dengan daging ayam karena melihat nutrisi yang lebih banyak daripada daging ayam, selain itu cita rasa daging bebek yang berbeda dengan ayam. 
Sehingga itu sekaligus yang membedakan segmen pasarnya. Harga daging bebek pun lebih mahal dibandingkan dengan daging ayam. Dan daging bebek menjadi makanan substitusi. UNGGAS KAMI hanya jual beli bebek lokal, bebek peking, dan bebek hybrida. Kemudian berkembang tidak hanya jual-beli saja tetapi dari mulai menetaskan telur, ternak, sampai mendistribusikannya, serta menjual pakan. Struktur organisasinya terdiri atas pimpinan kemudian di bawahnya dikuti bagian-bagian yang dibantu oleh pekerja. Bagian-bagian itu antara lain bagian produksi, bagian distribusi dan bagian keuangan. Tempat penggemukkan dengan kandang ukuran $10 \mathrm{~m}$ x $30 \mathrm{~m}$. Telur yang dibeli dari supplier disortir untuk diteteskan supaya berkembangbiak menjadi bebek, dimasukkan kedalam mesin penetas telur selama 28 hari. Biasanya telur yang menetes itu minimal $40 \%$ dari jumlah telur yang dibeli. Telur yang tidak menetas dijual kembali dapat dikonsumsi atau dibuat telur asin terlebih dahulu baru dijual. Selama proses 28 hari tersebut, telur di bolakbalikan sampai keluar bebek. Bebek tersebut digemukan/ternak di kandang supaya dapat dijual dengan permintaan rata-rata krakas 6ons daging atau disebut DOD (day old duck).

Promosi yang dilakukan dengan menggunakan blog, facebook, komunitas, iklan baris gratis. UNGGAS KAMI sudah menjangkau pasar pulau Jawa, untuk DOD (day old duck) dikirim melalui transportasi Kereta Api. Sedangkan pakan dan telur masih sekitar Jawa Barat didistribusikan menggunakan angkutan.

Analisis terkait kondisi dan potensi wilayah dari segi fisik, ekonomi, dan sosial maupun lingkungan yang relevan dengan kegiatan yang akan dilakukan adalah sebagai berikut :

1. Segi Fisik

Tempat pemasaran UNGGAS KAMI terletak di Kadungora-Garut tepat dipinggir jalan provinsi. Akses menuju lokasi ini dapat dijangkau baik dengan kendaraan roda dua, maupun dengan kendaraan roda empat. Untuk tempat penggemukan/ternak dan penetasan hanya dapat dijangkau oleh kendaraan roda dua, dikarenakan dekat dengan daerah lahan pesawahan.

Sarana dan prasarana yang dimiliki oleh UNGGAS KAMI antara lain sebagai berikut:
a. Kandang sebagai tempat penggemukan.
b. Alat produksi, berupa penetas telur kapasitas 1000 telur, thermostat, thermometer, hygrometer, genset.

2. Segi Sosial

Masyarakat sekitar wilayah Kadungora pada umumnya belum mengetahui UNGGAS KAMI, yang mengetahui konsumen, relasi dan komunitas. Yang dikenalnya hanya menjual telur bebek saja. Karena tempat pemasaran dengan tempat penggemukan dan tempat penetasan telur berbeda. Untuk media pemasaran melalui online seperti blog, facebook, iklan baris gratis biasanya konsumen yang tertarik komunikasi via telepon walaupun tidak mengetahui tempat keberadaannya. Jangkauan pemasarannya cukup luas karena pemasaran via internet, konsumen yang di luar Jawa Barat yang banyak mengenal UNGGAS KAMI ini.

\section{Segi Ekonomi}

UNGGAS KAMI merupakan usaha perorangan, sehingga secara ekonomi sisi permodalan terutama ekonomi, sehingga belum terpisahkan secara profesional antara modal, biaya produksi, piutang dan keuntungan yang diperoleh.

Masalah utama yang dialami oleh usaha UNGGAS KAMI sebagai berikut:

1. Mesin penetas telur baru memiliki satu dengan kapasitas 1000 telur, semakin banyak mesin penetas telur maka semakin banyak produksi telur untuk menghasilkan DOD. Setiap mesin penetas harus ada thermostat, thermometer dan hygrometer. Sehingga apabila mesin penetas bertambah, maka thermostat, thermometer dan hygrometer pun harus ada. Ini pun berpengaruh pada 
suplai listrik atau genset, karena mesin penetas telur menggunakan listrik selama proses penetasan 28 hari sehingga untuk mengantisipasi ketika supply listrik dari PLN padam tanpa pemberitahuan terlebih dahulu, dapat menggunakan genset. Kapasitas genset yang dimiliki 2 kva, oleh karena itu apabila mesin penetas bertambah kapasitas genset juga bertambah.

2. Perputaran uang untuk modal megalami kendala dikarenakan banyaknya piutang yang tidak tercatat. Terkait belum memahami penyusunan laporan keuangan. Saat ini mitra belum menyusun laporan keuangannya dan belum paham dalam menghitung modal, biaya produksi, piutang dan laba kotor.

3. Dari segi pemasaran, mitra akan ditawarkan packaging telur asin supaya memiliki daya jual lebih dan tidak hanya DOD yang dipasarkan melalui internet tetapi telur asin juga dapat dipasarkan melalui media promosi yang efektif. Pemanfaatan e-commerce dan perbaikan design merupakan salah satu langkah dalam meningkatkan pemasaran produk (Masnah, Hapid \& Header 2016; D.H. Wibowo \& Arifin, 2015)

4. Pembenahan pemasaran dengan pemasangan plang nama. Saat ini mitra tidak memiliki identitas atau plang nama di lokasi pemasaran..

\section{METODOLOGI PELAKSANAAN}

Metode pelaksanaan kegiatan pengabdian masyarakat ini fokus pada administrasi perapihan pencatatan keuangan dan media promosi mitra serta diharapkan dapat mengatasi segala permasalahan yang dihadapi oleh mitra. Menurut Pratama (2018), pemasaran hasil ternak ayam paling efektif dilakukan dengan cara penjualan secara manual yaitu ke pasar tradisional dan melalui media online.

Secara umum metode yang dilakukan adalah sebagai berikut:

1. Untuk mengatasi masalah dari segi fisik seperti belum terpenuhinya beberapa alat produksi yaitu mesin penetas, thermostat, thermometer, hygrometer dan genset maka kami menyediakan alat-alat tersebut.

2. Untuk mengatasi masalah dari segi sosial seperti masyarakat Garut secara umum terutama wilayah Kadungora belum mengetahui keberadaan UNGGAS KAMI maka kami mencoba membuat identitas dengan plang nama di tempat usaha mitra.

3. Membuat packaging design. Kami menawarkan packaging design yang dapat digunakan oleh mitra karena design menceminkan identitas suatu produk, meningkatkan daya tarik seta mampu melindungi produk (Lim, Tanudjaja \& Salamoon 2015) dan tentunya memiliki daya jual tinggi. Serta melakukan pelatihan untuk menggunakan media promosi yang efektif.

4. Melakukan pelatihan dalam penyusunan laporan keuangan berbasis EMKM. Kami menyediakan modul pelatihan sebagai pegangan mitra serta kami pun melakukan pendampingan selama 1 (satu) bulan hingga mitra terbiasa melakukan pencatatan transaksi keuangannya sendiri. Menurut Rahayu et al (2020) SAK EMKM hanya mewajibkan bagi entitas atau usaha yang telah memiliki badan hukum. Namun demikian perusahaan pribadi atau usaha yang belum berbadan hukum tetap dapat menggunakannya terutama yang sudah dapat memisahkan kekayaan pemilik dan usaha. Kami melakukan pelatihan dari mulai siklus akuntansi. Mengacu kepada Sibarani et al (2019), siklus akuntansi EMKM akan membantu para pemilik usaha dalam menjalankan usahanya. Bukan hanya memperlancar pencatatan keuangan, tetapi bermanfaat untuk perencanaan bisnis di masa yang akan datang.

Partisipasi mitra sangat penting dalam kegiatan pengabdian masyarakat ini. Kami memperdalam informasi berupa 
permasalahan yang dialami oleh mitra selanjutnya mencari solusi atas masalah tersebut. Mitra pun diberi pemahaman terhadap segala sesuatu yang belum dipahami misalnya dalam hal melakukan penyusunan laporan keuangan sederhana. Diharapkan apa yang kami berikan kepada mitra dapat bermanfaat dan digunakan untuk meningkatkan produktifitasnya

\section{HASIL DAN LUARAN}

Hasil dari kegiatan pengabdian pada masyarakat sesuai dengan metode yang digunakan adalah sebagai berikut:

1. Masalah dari segi fisik, mitra baru memiliki mesin penetas telur bebek satu dengan kapasitas 1.000 telur, maka kami membantu memberi mesin penetas telur dengan kapasitas 1.000 telur berserta perlengkapan seperti thermostat, thermometer dan hygrometer. Dengan bertambahnya mesin penetas telur tersebut, jumlah produksi telur menjadi lebih banyak dan DOD nya pun bertambah.

2. Untuk masalah dari segi sosial, karena mitra tidak memiliki lahan sesuai dengan kriteria peternak untuk penetasan dan penggemukan DOD. Mitra bergabung dengan komunitas peternak bebek yang lokasinya jauh dari akses angkutan umum. Untuk tempat pemasarannya saat ini mitra menggunakan rumah tempat tinggal yang lokasinya masuk gang. Maka dari itu kami tidak dapat melaksanakan pembuatan plang nama untuk mitra.

3. Memperbaharui design merek yang sudah ada, juga membuat packaging design telur dan packaging design DOD. Di mana untuk menambah nilai daya jual dan disertakan merek baru dalam packaging telur tersebut. Sedangkan kardus DOD yang digunakan untuk mengirim DOD ke pembeli, selama ini mitra menggunakan kotak tempat buahbuahan. Oleh karena itu kami memberikan packaging DOD dengan nama merek mitra. Untuk pelatihan yang dilakukan yaitu berupa diskusi terkait bagian pemasaran tentang segmenting, targeting dan positioning. Pengelolaan manajemen pemasaran yang baik dalam rangka meningkatkan daya saing, segmentasi pasar sehingga akan meningkatkan profit UMKM (Masnah, Hapid \& Header, 2016; D.H. Wibowo \& Arifin, 2015)

Desain Packaging telur dan DOD ini dapat dicetak di atas kertas stiker atau kertas lainnya. Desain tersebut dapat dilihat pada gambar berikut :

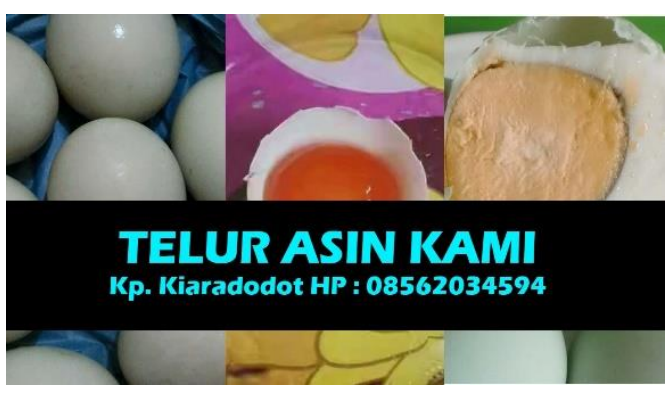

Gambar 1 : Desain Packaging

\section{UNGGAS KAMI}

\section{Gambar 2 : Desain DOD}

4. Dengan melakukan pelatihan dalam penyusunan laporan keuangan berbasis EMKM serta menyediakan modul pelatihan sebagai pegangan mitra, sejauh ini mitra mampu membuat laporan keuangan khususnya adalah laporan laba rugi. Adapun pengklasifikasian pendapatan diperoleh dari penjualan telur (baik telur yang akan ditetaskan maupun telur yang akan dikonsumsi) dan juga penjualan unggas yaitu bebek. Untuk pengklasifikasian biaya yang rutin dikeluarkan yaitu pembelian bohlam untuk memanaskan telur, pembelian telur tetas dan telur konsumsi, listrik, pakan unggas, dan upah pekerja. Mitra sudah mampu mengklasifikasikan mana yang termasuk 
dalam pendapatan dan mana yang termasuk dalam beban/biaya. Karena keterbatasan SDM, pencatatan keuangan ini masih dilakukan oleh mitra seorang diri sehingga terkadang memiliki keterbatasan waktu untuk membuatnya karena harus mengurus pekerjaan operasional keseharian juga. Sebisa mungkin mitra mengatur perputaran uang agar tidak terjadi defisit. Pencatatan yang belum dilakukan oleh mitra adalah pencatatan asset, hutang, dan modal.

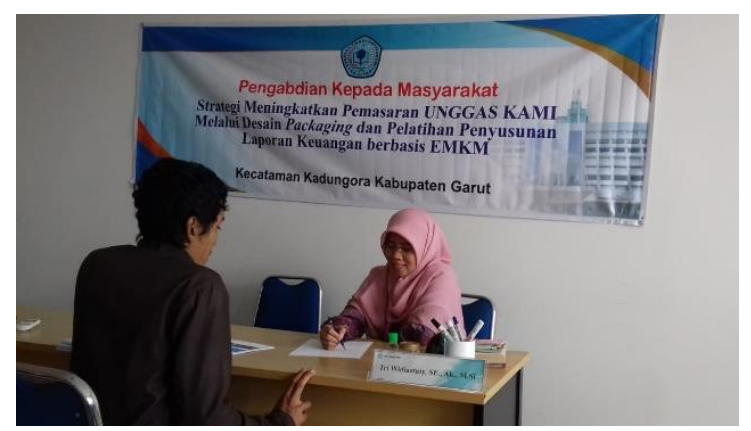

Gambar 3 : Pelatihan Penyusunan Laporan Keuangan

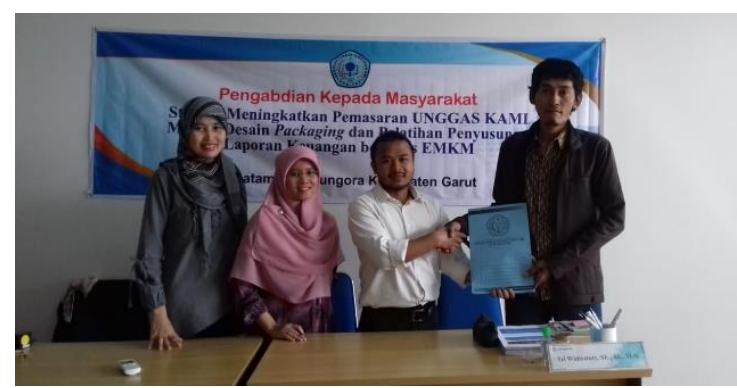

Gambar 4 : Pelatihan Penyusunan Laporan Keuangan

\section{KESIMPULAN DAN SARAN}

Dari permasalahan yang dialami oleh mitra mulai dari permasalahan keterbatasan alat, segi pemasaran, dan segi keuangan, kami mencoba memberikan solusi yang sekiranya dapat membantu mitra dengan harapan dapat meningkatkan omzet di masa yang akan datang. Pengadaan alat penetas telur, redesign merek yang sudah ada, dan melakukan pelatihan pencatatan keuangan sederhana kepada mitra menjadi hal yang kami pilih untuk membantu mitra. Kami pun berharap kegiatan pengabdian ini dapat menjadi langkah awal untul pengambangan usaha mitra di masa depan.

\section{DAFTAR PUSTAKA}

Lim, S., Tanudjaja, B. B., \& Salamoon, D.

K. (2015). Perancangan Kemasan Produk" Choco Molten" Online Bakery Instacake Sebagai Media Promosi. Jurnal DKV Adiwarna, 1(6), $1-12$.

Masnah, M., Hapid, H., \& Haedar, H. (2016). Strategi Pemasaran Industri Kue Bagea Dalam Meningkatkan Volume Penjualan Di Masamba Kabupaten Luwu Utara. Jurnal Equilibrium, 2(1), 35-39.

Wibowo, D. H., \& Arifin, Z. (2015).

Analisis Strategi Pemasaran Untuk Meningkatkan Daya Saing Umkm (Studi pada Batik Diajeng Solo). Jurnal Administrasi Bisnis, 29(1), 5966.

Rahayu, Sri Mangesti, Wita Ramadhanti, dan Taufik Margi Widodo. 2020. Akuntansi Dasar Sesuai dengan SAK EMKM. Yogyakarta: Deepublish.

Sibarani, et al. (2019). Dasar-Dasar Kewirausahaan. Yayasan Kita Menulis. 